\title{
Centers for Oceans and Human Health: contributions to an emerging discipline Edward A Laws ${ }^{1}$, Lora E Fleming ${ }^{2}$ and John J Stegeman*3
}

\begin{abstract}
Address: ${ }^{1}$ School of the Coast and Environment, $1002 \mathrm{~K}$ Energy, Coast and Environment Building, Louisiana State University, Baton Rouge, Louisiana 70803-4110, USA, 2Departments of Epidemiology \& Public Health and Marine Biology \& Fisheries, Miller School of Medicine and Rosenstiel School of Marine and Atmospheric Sciences, University of Miami, Clinical Research Building, 10th Floor (R669), 1120 NW 14th Street, Miami, Florida, USA and '3Woods Hole Oceanographic Institution, Woods Hole Center for Oceans and Human Health, Woods Hole, MA 02543, USA

Email: John J Stegeman* - jstegeman@whoi.edu

* Corresponding author
\end{abstract}

from Centers for Oceans and Human Health Investigators Meeting

Woods Hole, MA, USA. 24-27 April 2007

Published: 7 November 2008

Environmental Health 2008, 7(Suppl 2):SI doi:10.1I86/I476-069X-7-S2-SI

This article is available from: http://www.ehjournal.net/content/7/S2/SI

(c) 2008 Laws et al; licensee BioMed Central Ltd.

This is an open access article distributed under the terms of the Creative Commons Attribution License (http://creativecommons.org/licenses/by/2.0), which permits unrestricted use, distribution, and reproduction in any medium, provided the original work is properly cited.

The oceans are the dominant feature of the planet and are fundamentally linked to human history and to human health. Concerns about the impact of the oceans on human health can be traced to ancient times. Jewish law prohibited the consumption of shellfish, probably reflecting the fact that filter-feeding bivalves can accumulate pathogens and toxins. The Portuguese explorer Pedro Fernandes de Queirós described symptoms associated with ciguatera fish poisoning after eating Caribbean sea bream in 1606, and several of British explorer James Cook's crew experienced similar symptoms after eating fish off the coast of Vanuatu in 1774 [1]. Roughly 1,200 people died from the consumption of fish and shellfish contaminated with methyl mercury in Minamata (Japan) during the $20^{\text {th }}$ century; an even larger number were affected by chronic long-term neurotoxicological impacts [2]. A tsunami caused by an undersea earthquake on December 26, 2004 killed more than 225,000 people in eleven countries bordering the Indian Ocean; and more than 1,400 people died within a single day when the storm surge generated by Hurricane Katrina overwhelmed the New Orleans levee system on August 29, 2005 [3]. Looking ahead, the International Panel on Climate Change has projected a sea level rise of as much as $88 \mathrm{~cm}$ during the $21^{\text {st }}$ century as a result of global warming [4], with major implications for the welfare and sustainability of coastal communities.

Despite concerns about biological, physical and chemical risks, and the possible long-term effects of global warming, the oceans remain a resource of immense value to mankind. Many marine fish and shellfish, for example, are excellent sources of protein, selenium, and omega-3 polyunsaturated fatty acids. Around the globe, the coastal ocean is a recreational destination for a substantial percentage of the human population as well as a venue of intensive commercial activity. In 1999, the National Research Council (NRC) published From Monsoons to Microbes: Understanding the Oceans Role in Human Health [5], a seminal document that examined both positive and negative implications of ocean phenomena for human health. The NRC report catalyzed a series of reports [6-11] and activities related to the impacts of the ocean on human health and human impacts on oceans, and suggested how efforts could be directed to anticipate and respond to health needs and threats.

Recognizing the growing need for interdisciplinary basic and applied research addressing the linkages between human health and the oceans, in 2004 the National Science Foundation (NSF) and the National Institute of Envi- 
ronmental Health Science (NIEHS) jointly funded grants establishing four Centers for Oceans and Human Health $(\mathrm{COHH})$. These centers are: (i) the Oceans and Human Health Center at the University of Miami, (ii) the Pacific Research Center for Marine Biomedicine at the University of Hawaii, (iii) the Pacific Northwest Center for Human Health and Ocean Studies at the University of Washington, and (iv) the Woods Hole Center for Oceans and Human Health at the Woods Hole Oceanographic Institution, the Marine Biological Laboratory, and Massachusetts Institute of Technology. Through an internal competitive process, the National Oceanic and Atmospheric Administration (NOAA) in the same year designated three NOAA centers of excellence in oceans and human health under their Oceans and Human Health Initiative (OHHI): (i) the West Coast Center for Oceans and Human Health at the Northwest Fisheries Science Center in Seattle, Washington, (ii) the NOAA Center of Excellence in Oceans and Human Health at the Hollings Marine Laboratory in Charleston, South Carolina, and (iii) the NOAA Center of Excellence for Great Lakes and Human Health at the Great Lakes Environmental Research Laboratory in Ann Arbor, Michigan. The NOAA initiative also includes external competitive grant, distinguished scholar, and traineeship programs.

In the United States, one of the motivations for $\mathrm{OHH}$ research arises from the fact that some 62 million Americans swim in the coastal waters of the United States and spend 800 million person-days at beaches annually [12]. Wound, eye and ear infections that can result from pathogen exposure often go unreported, but may be serious; for example, $V$. vulnificus wound infections have a death rate of some 50\% [13]. Public awareness of the healthful characteristics of many seafoods is reflected by increasing per capita seafood consumption by U.S. citizens to more than $7 \mathrm{~kg}$ per year in 2003. However, the presence of algal toxins and chemical pollutants in some seafood products, and exposure to microbial contaminants (such as Vibrio bacteria and Noroviruses) as a result of the consumption of raw and even cooked molluscan shellfish remain a concern $[14,15]$. The economic costs associated with the impact of harmful algal blooms (HABs) on public health have been estimated to be at least $\$ 20$ million per year in the United States; while in Southern California alone, the medical costs associated with microbial contamination of recreational beaches range between $\$ 20$ million and $\$ 50$ million per year [12].

Oceans and Human Health is a growing integration of several disciplines, from physical oceanography to molecular biology to epidemiology, emerging largely from the recognition that ocean processes have important implications for public health, and human activities can influence these processes. Details on approaches to this new area of concern may be found in the Interagency Oceans and Human Health Research Implementation Plan [16]. The five articles in this Oceans and Human Health Supplement issue of Environmental Health were conceived at a joint meeting of investigators from the NSF/NIEHS and the NOAA Oceans and Human Health Centers. Their intent is to articulate some of the challenges that lie ahead in this new multi-disciplinary area of scientific research [17]. The papers focus in part on prevention, particularly for HABs and pathogens, since one strategy in Oceans and Human Health is to "get ahead of the curve", i.e., to warn the public and resource managers before morbidity and mortality rates start to rise.

\section{Microbial pathogens and $\mathrm{OHH}$}

The primary concern regarding microbial pathogens is human exposure associated with the recreational and commercial use of coastal waters containing either indigenous or introduced pathogens. The primary route of transmission is the consumption of seafood, but can occur also by contact with seawater or exposure to marine aerosols and zoonoses. Almost all major bacterial lineages that contain human pathogens have also been detected in samples from ocean environments or organisms[18]. Yet for only few of these pathogens are tests available, and even fewer are routinely monitored [18].

For years, the standard strategy for monitoring introduced pathogens has been measuring the concentration of socalled fecal indicator bacteria (FIB). There are acknowledged and serious problems associated with the use of FIB for this purpose [19]. These include the facts that: (i) there is large spatial and temporal variability in FIB concentrations at recreational beaches, particularly in sub/tropical areas; (ii) FIB are not uniquely diagnostic for human fecal pollution; (iii) FIB may or may not survive in the environment as long as some of the hardier fecal pathogens (e.g., infectious hepatitis) for which they are the alleged surrogates; (iv) the standard assays for FIB take 24-48 hours; (v) only some strains of pathogenic microorganisms are highly virulent; and (vi) FIB provide no indication of the presence or abundance of non-enteric pathogens (e.g., Staphyllococcus aureus, Naegleri fowleri and Legionella pneumophila). Recent epidemiological studies conducted at recreational beaches impacted by non-point source pollution have revealed no statistically significant correlation between FIB concentrations and morbidity [19]. These issues are being addressed through a multidisciplinary and innovative strategy, including: (i) tests for microbes truly diagnostic of human and animal fecal pollution; (ii) molecular assays that are far more rapid than culture techniques; (iii) tests for the presence of virulence genes; (iv) the use of sentinel species and habitats [12,19]; and (v) the use of mathematical models to fill in spatial and tem- 
poral gaps in the data, and predict the behavior of complex systems [20].

Polymerase chain reaction methods for example, are being used to rapidly and specifically target microbes of public health concern, including those not examined previously because of an inability to culture them. New molecular assays have been introduced for detection of FIB, bacterial pathogens, viral pathogens, and protistan (protozoan) parasites. And recent methodological improvements are allowing simultaneous detection of multiple targets in a single assay. Scientists from MIT in the Woods Hole Center, in collaboration with colleagues from Northwestern University, have recently developed a protocol involving DNA microarrays that enables accurate identification of specific bacterial sequences in natural samples. Applied to environmental samples, the microarrays are able to detect Vibrio cholerae at natural concentrations in New England estuarine water, suggesting that microarrays may be applicable to broad environmental monitoring of co-occurring pathogens [19]. OHH researchers are working with the Southern California Coastal Water Research Project and the U. S. Environmental Protection Agency to evaluate the potential for such novel microbial detection technologies to forecast human health risks at California beaches contaminated with nonpoint sources of pollution. Researchers at the University of Miami are currently conducting an epidemiological study at Florida beaches impacted by non-point source pollution in collaboration with the U.S. Centers for Disease Control and Prevention and Florida Dept of Health [19].

\section{Harmful algal blooms (HAB) and OHH}

The acronym "HAB" is somewhat misleading since some HAB-designated problems (e.g., ciguatera fish poisoning), though caused by algae, are not associated with blooms in any conventional sense of the word, and others are caused by cyanobacteria, which are prokaryotic and, strictly speaking, not algae. Regardless, there are a variety of human health problems associated with HABs. The most common is acute (and in some cases, chronic) intoxication resulting from the consumption of shellfish or finfish that contain neurotoxins produced by HABs [21]. Other problems include respiratory irritation caused by the inhalation of aerosolized toxins produced by HABs, and the presence of $\mathrm{HAB}$ toxins in drinking water supplies, as in the Great Lakes.

In some cases remote sensing has been very successful in detecting HABs (and warning the public). A good example is detection of Karenia brevis blooms off the west coast of Florida by scientists at the University of Miami COHH in collaboration with NOAA OHH researchers [21]. Scientists at the University of Washington COHH have devel- oped a prototype antibody-based sensor for the detection of domoic acid, the neurotoxin that causes amnesic shellfish poisoning, and are collaborating with the University of Hawaii COHH and the Hollings Marine Laboratory to develop a similar probe for ciguatoxin [21]. In Puget Sound, the toxicity of shellfish is being monitored as a proxy to detect $\mathrm{HAB}$ events, as monitoring of phytoplankton abundance and composition is not sufficiently frequent [22]. As with pathogens, mathematical models have been used to integrate information from field studies and, in combination with biological mechanisms, to gain insight into the processes that trigger algal blooms. One of the best examples of this approach has been the hindcasting of Alexandrium fundyense blooms in the Gulf of Maine by the Woods Hole COHH $[20,21,23]$.

A concern with modeling and forecasting is the growing awareness that the abundance and, in particular, the toxicity of HAB species may not be explainable solely in terms of the physics and chemistry of the environment. Interactions with bacteria and/or viruses, for example, may play an important role in toxin production. Interactions with bacteria appear to play a role in the production of the neurotoxin, domoic acid, by the diatom, Pseudonitzschia [21]. The importance of such species interactions has been established also among pathogens; Vibrio cholerae, for example acquires the cholera toxin gene via phage transduction [19],

Another emerging issue has been the discovery by scientists at the Hawaii $\mathrm{COHH}$ and others that the neurotoxin, $\beta-\mathrm{N}$-methylamino-L-alanine (BMAA), is produced by all known groups of cyanobacteria [21]. BMAA has been suggested to contribute to neurodegenerative diseases such as amylotrophic lateral sclerosis (ALS)/Parkinson's Disease and Alzheimer's-dementia and similar diseases in humans and animals [24]. It may find its way into the diets of humans and wildlife through the consumption of cyanobacteria, food chain magnification, and/or exposure to contaminated water supplies [21]. Currently, our concern about the impact of most HAB toxins on human health, and consequently our ability to mitigate the risks, is based largely on risks from acute exposures. However, there is growing concern about potential risks associated with long-term exposure to BMAA or HAB-associated toxins. Consumption of drinking water and/or seafood, for example, might result in chronic exposure to low levels of toxins, at concentrations below regulatory levels or even conventional detection limits [21].

\section{Global change and $\mathrm{OHH}$}

In terms of human health effects worldwide, a very important yet poorly understood issue emerging in $\mathrm{OHH}$ is the potential impact of climate change on the ecology of pathogens and harmful algal species. Among the eukaryotic 
microalgae, dinoflagellates are expected to benefit from a warmer climate and more thermally stratified water column [22]. Most HAB species are dinoflagellates. Global warming is expected to accelerate hydrological cycles, with resultant increases in stream runoff to coastal waters surrounding much of Asia and North and South America. Nutrient loading associated with increased coastal runoff may trigger more frequent blooms of HA species in the oceans and in fresh waters [22]. One of the proposed strategies for mitigating the impact of anthropogenic $\mathrm{CO}_{2}$ emissions, fertilization of large areas of the ocean with iron, could also stimulate HABs. Field studies of the impact of iron fertilization by researchers at the Hawaii OHH Center have indicated that pennate diatoms are the primary beneficiaries of iron fertilization; Pseudo-nitzschia, the genus containing a number of species associated with the production of the neurotoxin domoic acid and amnesiac shellfish poisoning, is particularly responsive [22].

\section{Outreach and education}

Various agencies, in part through the Centers, are helping to train a new generation of scientists in the interdisciplinary aspects of $\mathrm{OHH}$ through the participation of students and post-docs in OHH research projects and related activities, including the NSF-funded $\mathrm{OHH}$ research experience for undergraduates (REU) program and a new NOAAfunded OHH Traineeship Program.

Collaborations among the various $\mathrm{OHH}$ centers and other $\mathrm{OHH}$ researchers have: (i) produced a noteworthy multicenter and interdisciplinary microbiological study of New Orleans and Lake Pontchartrain following Hurricane Katrina [25]; (ii) produced a special edition of Oceanography on $\mathrm{OHH}$ [26] and a textbook on $\mathrm{OHH}$ [27]; and (iii) helped facilitate the organization of multiple sessions on $\mathrm{OHH}$ at the 2006 and 2008 AGU/ASLO/TOS Ocean Sciences meetings, as well as a variety of other symposia, workshops, and meetings and a new Gordon Research Conference-supported conference and Graduate Research Seminar on Oceans and Human Health http:www. grc.org/programs.aspx? year=2008\&pro

gram=oceans. Synergistic and collaborative contributions to the ongoing work of the Interagency Working Group on Harmful Algal Blooms, Hypoxia and Human Health have played an important role in the success of the Working Group in producing the first comprehensive assessment of the status of $\mathrm{OHH}$ research and opportunities for advancement in this new field [17]. Hopefully, the current volume will provide a perspective on the current status in several areas, which may stimulate further efforts in this young and globally important endeavor and scientific discipline.

\section{Competing interests}

The authors declare that they have no competing interests.

\section{Acknowledgements}

A number of people, especially Elaine Faustman, Juli Tritanj and Paul Sandifer, made comments on the manuscript. The support of the National Science Foundation (US) and the National Institute of Environmental Health Sciences (US) is gratefully acknowledged: Grant numbers NSF OCE0432479 and NIEHS P50 ESO 2740 (EAL), NSF OCE-0432368 and NIEHS P50 ESI 2736 (LEB), and NIEHS P50 ESOI 2742 and NSF OCE-043072 (JJS).

This article has been published as part of Environmental Health Volume 7, Supplement 2, 2008: Proceedings of the Centers for Ocean and Health Investigators Meeting. The full contents of the supplement are available online at http://www.ehjournal.net/supplements/7/S2.

\section{References}

I. Helfrich P: Fish poisoning in Hawaii. Hawaii Med J 1963, 22:36I-372

2. Smith WE, Smith AM: Minmata. New York: Holt, Rinehart, and Winston; 1975.

3. Laska S, Morrow BH: Social vulnerabilities and Hurricane Katrina: An unnatural disaster in New Orleans. Marine Technology Society Journal 2007, 40(4): 16-26.

4. Climate Change 2007 [http://www.ipcc.ch/]

5. NRC: From Monsoons to Microbes: Understanding the Ocean's Role in Human Health. Washington, D.C.: National Academy Press; 1999.

6. Tyson FL, Rice DL, Dearry A: Connecting the oceans and human health. Environmental Health Perspectives 2004, I I 2(8):A455-A456.

7. Stegeman JJ, Solow AR, Goehl TJ: Environmental health and the coastal zone. Environmental Health Perspectives 2002, I I O(II):A660-A66I.

8. Knap A, Dewailly E, Furgal C: Indicators of ocean health and human health: A research framework. Environmental Health Perspectives 2002, I I 0:839-845.

9. America's Living Oceans: Charting a Course for Sea Change [http://www.pewtrusts.org/pdf/env pew oceans final report.pdf]

10. An Ocean Blueprint for the 2 I $^{\text {st }}$ Century [http://www.ocean commission.gov/documents/full color rpt/

000 ocean full report.pdf

1I. Sandifer PA, Holland AF, Rowles TK, Scott GI: The oceans and human health. Environmental Health Perspectives 2004, I I 2(8):A454-455.

12. Kite-Powell HL, Fleming LE, Backer LC, Faustman EM, Hoagland P, Tsuchiya A, Younglove L, Wilcox BA, Gast RJ: Linking the oceans to public health: Where is the "human health" in "oceans and human health"? Environ Health 2008, 7(Suppl 2):S6.

13. Oliver JD: Vibrio vulnificus. In Oceans and Health:Pathogens in the Marine Environment Edited by: Belkin S, Colwell RR. Springer; 2006:253-276.

14. Nesheim MC, Yaktine AL, (eds): Seafood Choices: Balancing Benefits and Risks. Washington, D.C.: National Academies Press; 2007.

15. Dickoff WW, Collier TK, Varanasi U: The seafood "dilemma" - a way forward. Fisheries 2007, 32:244-246.

16. Fleming LE, Broad K, Clement A, Dewailly E, Elmir S, Knap A, Pomponi SA, Smith S, Solo-Gabriele H, Walsh PJ: Oceans and Human Health: Emerging Public Health Risks in the Marine Environment. Marine Pollution Bulletin 2006, 53:545-560.

17. Sandifer PA, Sotka C, Garrison D, Fay V: Interagency oceans and human health research implementation plan: a prescription for the future. Interagency Working Group on Harmful Algal Blooms, Hypoxia and Human Health of the Joint Subcommittee on Ocean Science and Technology 2007:92.

18. Thompson JT, Marcelino L, Polz MF: Diversity and sources of human bacterial pathogens and overview of methods of their detection and quantification. In Ocean and Health: Pathogens in the Marine Environment Edited by: Belkin S, Colwell RR. Springer; 2005:29-68.

19. Stewart JR, Gast RJ, Fujioka RS, Solo-Gabriele HM, Meschke JS, Amaral-Zettler LA, Castillo ED, Polz MF, Collier TK, Strom MS, et al.: The coastal environment and human health: microbial indicators, pathogens, sentinels and reservoirs. Environ Health 2008, 7(Suppl 2):S3.

20. Dyble J, Bienfang P, Dusek E, Hitchcock G, Holland F, Laws EA, Lerczak J, McGillicuddy DJ Jr, Minnett P, Moore SK, et al.: Environmental 
controls, oceanography and population dynbamics of pathogens and harmful algal blooms: Connecting sources to human exposure. Environ Health 2008, 7(Suppl 2):S5.

21. Erdner DL, Dyble J, Brand LE, Parker MS, Stevens RC, Moore SK, LeFebvre K, Bienfang P, Anderson DM, Bidigare RC, et al.: Centers for oceans and human health: A unified appraoch to the challenge of harmful algal blooms. Environ Health 2008, 7(Suppl 2):S2.

22. Moore SK, Trainer VL, Mantua NJ, Parker MS, Laws EA, Backer LA, Fleming LE: Centers for oceans and human health: Climate variability, climate change and harmful algal blooms. Environ Health 2008, 7(Suppl 2):S4

23. He R, McGillicuddy D, Keafer BA, Anderson DM: Gulf of Maine harmful algal bloom in summer 2005 - Part 2:Coupled biophysical numerical modeling. Journal of Geophysical Research Oceans 2008 in press.

24. Metcalf JS, Banack SA, Lindsay JA, Morrison LF, Cox PA, Codd GA: Co-occurrence of $\beta-\mathrm{N}$-methylamino-L-analine, a neurotoxic amino acid with other cyanobacterial toxins in British waterbodies, 1990-2004. Environmental Microbiology 2008, I 0(3):702-708.

25. Sinigalliano $C D$, Gidley ML, Shibata $T$, Whitman $D$, Dixon $T H$, Laws EA, Hou AX, Bachoon D, Brand L, Amaral-Zettler L, et al.: Impacts of Hurricane Katrina on microbial landscape of the New Orleans area. Proc Natl Acad Sci USA 2007, 104:9029-9034.

26. Fleming LE, Laws EA, (eds): Oceanography. Rockville, MD: The Oceanography Society; 2006.

27. Walsh PJ, Fleming LE, Solo-Gabriele HM, Gerwick WH, (eds): Oceans and Human Health: Risks and Remedies from the Sea. New York, NY: Elsevier, 2008.

Publish with Bio Med Central and every scientist can read your work free of charge

"BioMed Central will be the most significant development for disseminating the results of biomedical research in our lifetime. "

Sir Paul Nurse, Cancer Research UK

Your research papers will be:

- available free of charge to the entire biomedical community

- peer reviewed and published immediately upon acceptance

- cited in PubMed and archived on PubMed Central

- yours - you keep the copyright 